\title{
Fostering and Advancing Inclusion and Diversity as Corporate's Key Strategies to Sustain in Global Competitiveness
}

\author{
Priyo Yantyo, Syahrizal Maulana \\ Center for Innovation \\ Indonesian Institute of Sciences (LIPI) \\ Cibinong, Indonesia \\ priyo.yantyo@lipi.go.id
}

\begin{abstract}
Diversity can be defined across six clear demographic strands: gender, age, race \& ethnicity, sexual orientation, religion \& beliefs, and disability. Finding new and better solutions, innovating, requires thinking differently. Transforming an idea into a new process, product or service to generate a competitive advantage, which depends as much on collective difference as on aggregate ability. Companies need a steady stream of products, services, marketing strategies, and sales plans that exceed their existing and prospective customers' expectations. One of the corporate's key strategies was to plug into diversity in all its forms, to energize creativity and make innovation a more natural and organic process. Today's global competition impact the need for productivity, innovation, and creativity that leverages diversity in entire business's ecosystem, through: (i) re-evaluating product line based on consumers and businesses which becoming more diverse, educated, and demanding, (ii) hiring employee, expertise and partners from diverse background and different specialist fields, and (iii) finding way to directly engage the customers as community to gain powerful insight into their demands. They must do this more quickly and better than their competitors. This research aims to assess insights and perspectives regarding the future of diversity and some of the new best practices that will allow diversity to play a more strategic role in cultivating sustainable business growth.
\end{abstract}

Keywords - inclusion; diversity; innovation; sustainable; competitiveness

\section{INTRODUCTION}

Diversity derived from four different frames of references: differences, experiences, systems and culture. In the term of demographic strands, diversity frame is identified as primary and secondary differences [1]. Primary differences are given as born and have strong and life-long impact on life: race, gender, sexual orientation, physical and mental ability, ethnicity and age. Secondary differences are the differences acquired and sometimes discard or modify over time, based on the life decisions we make: religion, class, income, education, etc.

\section{A. Global market and diversity challenges}

Many companies began entering global markets and challenge themselves to obtain manpower capable of performing in a new-competing international setting. Mature economy countries gives competitive pressures, urges companies seeks and shift into new markets segments with customers from un-serviced demographic groups and expanding their labor forces into population who represent them as well. Regarding this circumstance, diversity should be managed for profit, organizational advantage, success and survival, since it has become an economic value [2].

Millennial companies are demanding by diversity in many aspects todays. Demographic advance in workforce layout and customer populations, combined with globalized markets and international competition are increasing the amount of diversity area of organizations must manage, both internally and externally. Many diversity experts and business leaders stick into that businesses concern of bearing and pursuing succeed in the twenty-first century need to catch competitive advantage from a diverse workplace $[3,4]$.

\section{B. Diversity program, business performance and innovation}

McKinsey \& Company research shows that companies with minority and women participation have financial returns $35 \%$ and $15 \%$ above their competitor, respectively. Data suggests that adopt a single diversity program to cover all differences is insufficient, because it prevent companies to address it as a whole issue [5]. Deloitte research result that about $29 \%$ of the companies are quite exceptional talent companies based on Talent Maturity Model, that look at leadership and inclusion as a hallmark of their talent strategy. These companies have 2.3 times higher cash flow per employee over a three-year period and 1.8 times more likely to be change-ready and 1.7 times more likely to be innovation leaders in their market [6].

Diversity Inc. (www.diversityinc.com) mentions the success of companies that conduct recruitment of diverse workforce, among others, AT\&T (rank \#4 in the D\&I list 2016) always embraced diversity from Board to executives to retail and service employees to suppliers [7]. AT\&T have the most managers in training (36.5\% higher than the Top 10) and comprehensive leadership development programs, online courses, and resources helps employees achieve their personal and professional goals. 


\section{Diversity management}

Diversity management is applied behavioral science methodology to manage organizational change and eliminate oppression based on human differences, in order to improve the effectiveness of organizations, while affirming the values of respect for human differences, social justice, participation, community, authenticity, compassion, pro-action and humility.

\section{METHODOLOGY}

This paper was constructed by qualitative method using literature study and discussion based on descriptive data analysis. Literature study has been done by searching referenced material through paper based sources e.g. books, journals, articles and official government website and organizations. Next step is to refine data and information obtained by approaching and to analyze descriptively to find out the insights and perspectives regarding the future of diversity and some of the new best practices that will allow diversity to play a more strategic role in cultivating sustainable business growth.

\section{DISCUSSION}

\section{A. Best practice: organizational diversity management}

Best practices are contemporary defined as "practices that are most appropriate under the circumstances, esp. as considered acceptable or regulated in business; techniques or methodologies that, through experience and research, have reliably led to desired or optimum results" [8]. Research in investigating diversity management practices to resolve whether it will achieve 'desired or optimum' results is one of the challenges in finding its best practices $[9,10,11]$. Todays, many organizations are treasure that diversity can be a determinant of competitive advantage. Various arguments have been established to back this perspective. They believe that diversity can be a source of competitive advantage in the global marketplace.

There are few resources for diversity management best practices of business perspective. Article on "Managing the diversity revolution: Best practices for 21 st century business", Aronson noted that managing diversity in a fine way, addressed to be having positive potency, spark creativity, dynamism and merit, revitalizing and reviving the corporation, and ultimately improving the key point rather than only for avoiding negative impacts of object itself. There are five different arguments in favor of diversity: resource-acquisition, resourcemaximization, creative problem solving, marketing and globalization [12]. These arguments have been proposed for how they contribute to competitiveness. These are illustrated in Fig. 1.

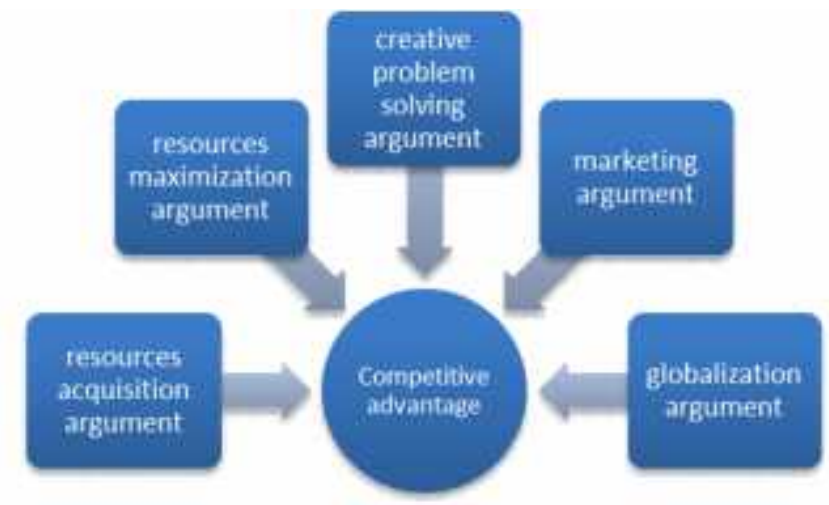

Fig. 1. Arguments of diversity as contribution for competitive advantage

The cost argument suggests that organizations that learn to manage diversity generally have higher levels of productivity and lower levels of turnover and absenteeism. Work atmosphere believes as root cause of turnover, rather than money consideration. Management practices can be directly traced to environmentally contributor to turnover, exclusively in diverse workplace. Diversity in a workplace is like backsword, it generates much benefits if it is well managed, but causes greater risk of turnover if it does not well maintained. Employee turnover has a direct impact on costs, moreover retirement of experienced employee causes extreme lost of productivity and high rates of turnover. Former organization remains more competitive than will the latter.

The resource acquisition argument suggests that organizations who manage diversity effectively become known among women and minorities as good places to work. These organizations are thus better able to attract qualified employees from among these groups. Given the increased importance of these groups in the overall labor force, organizations that can attract talented employees from all segments of society are likely to be more competitive.

The marketing argument suggests that organizations with diverse and multicultural workforces are better able to understand different market segments than are less diverse organizations. Company that wants to sell products to women and blacks can better understand how to create such products and effectively market them if women and black managers are available to provide inputs into product development, design, packaging, advertising, and so forth.

The creativity argument suggests that organizations with diverse and multicultural workforces are generally more creative and innovative than other organizations. If an organization is dominated by one population segment, it follows that its members will generally adhere to norms and ways of thinking that reflect that segment. Moreover, they have little insight or stimulus for new ideas that might be derived from different perspectives. The diverse and multicultural organization, in contrast, is characterized by multiple perspectives and ways of thinking and is therefore more likely to generate new ideas and ways of doing things. 
Related to the creativity argument is the problem-solving argument. Diversity is accompanied by an increased pool of information. In virtually any organizations, there is information that everyone has and other information that is unique to each individual. In an organization with little diversity, the larger pool of information is common and the smaller pool is unique. But in a more diverse organization, the unique information is larger. Thus, because more information can be brought to bear on a problem, there is a higher probability that better solutions can be identified.

Finally, the systems globalization argument suggests that organizations must become more flexible as a way of managing a diverse and multicultural workforce. As a direct consequence, the overall organizational system also becomes more global. Organizational flexibility enables the organization to better respond to changes in its environment.
Thus, by effectively managing diversity within its workforce, an organization simultaneously becomes better equipped to address its environment.

Table 1 lists selected Fortune 500 companies on D\&I 50 Rank which listed more than 8 years (except General Motors, purposely chosen represented as Fortune Top 10) and where Fig. 2 shows its rank history on Fortune 500. Seventeen out of 50 fortune 500 sorted companies which listed on DiversityInc 50 between 2001-2016, have more listed year than others, at least listed 9 times. In 2016, These companies lay between rank 10 of Fortune 500 (General Motors, rank 4 on D\&I) and rank 294 of Fortune 500 (MasterCard, rank 294 on D\&I). They have increasing revenue between 2001-2016, as their Fortune 500 increase (increasing Fortune 500 rank represents increasing revenues, certainly). Fig. 2 shows that fact.

TABLE I. SELECTED DIVERSITY AND INCLUSION (D\&I) COMPANIES RANK

\begin{tabular}{|l|l|l|}
\hline \multicolumn{1}{|c|}{ D\&I Rank (2016) } & Fortune Rank (2016) & \multicolumn{1}{c|}{ Number of listed years (2001-2016) } \\
\hline 4. AT\&T & $\# 10, \$ 146.8 \mathrm{~B}$ & 11 (ent2001,out2002-2006) \\
\hline 7. MasterCard & $\# 294, \$ 9.6 \mathrm{~B}$ & 9 (ent2001,out2002-2004,2005-2007,2010) \\
\hline 8. Johnson \&Johnson & $\# 39, \$ 70.1 \mathrm{~B}$ & 12 (ent2001,out2003-2006) \\
\hline 9. Marriott International & $\# 195, \$ 13.8 \mathrm{~B}$ & 15 (ent2001,out2002) \\
\hline 10. Prudential Financial & $\# 50, \$ 57.1 \mathrm{~B}$ & 16 (ent2001) \\
\hline 12. Wells Fargo & $\# 27, \$ 90 \mathrm{~B}$ & 15 (ent2002) \\
\hline 13. Procter \& Gamble & $\# 34, \$ 78.8 \mathrm{~B}$ & 13 (ent2002,out2003,2006) \\
\hline 14. Abbott & $\# 138, \$ 20.6 \mathrm{~B}$ & 13 (ent2004) \\
\hline 17. Merck \& Co. & $\# 72, \$ 39.5 \mathrm{~B}$ & 14 (ent2003) \\
\hline 19. Cummins & $\# 148, \$ 19.1 \mathrm{~B}$ & 10 (ent2007) \\
\hline 20. IBM & $\# 31, \$ 82.5 \mathrm{~B}$ & 13 (ent2001,out2005-2007) \\
\hline 32. Aetna & $\# 46, \$ 60.3 \mathrm{~B}$ & 10 (ent2001,out2002,2004-2008) \\
\hline 35. Allstate Insurance Company & $\# 81, \$ 35.2 \mathrm{~B}$ & 13 (ent2001,out2008-2010) \\
\hline 36. Colgate-Palmolive & $\# 174, \$ 16 \mathrm{~B}$ & 13 (ent2001,out2002,2003,2008) \\
\hline 40. General Mills & $\# 161, \$ 17.6 \mathrm{~B}$ & 12 (ent2004,out2006) \\
\hline 43. Monsanto & $\# 189, \$ 15 \mathrm{~B}$ & 9 (ent2008) \\
\hline 48. General Motors & $\# 8, \$ 152.3 \mathrm{~B}$ & 7 (ent2001,out2003,2006,2009-2015) \\
\hline & & \\
\hline
\end{tabular}




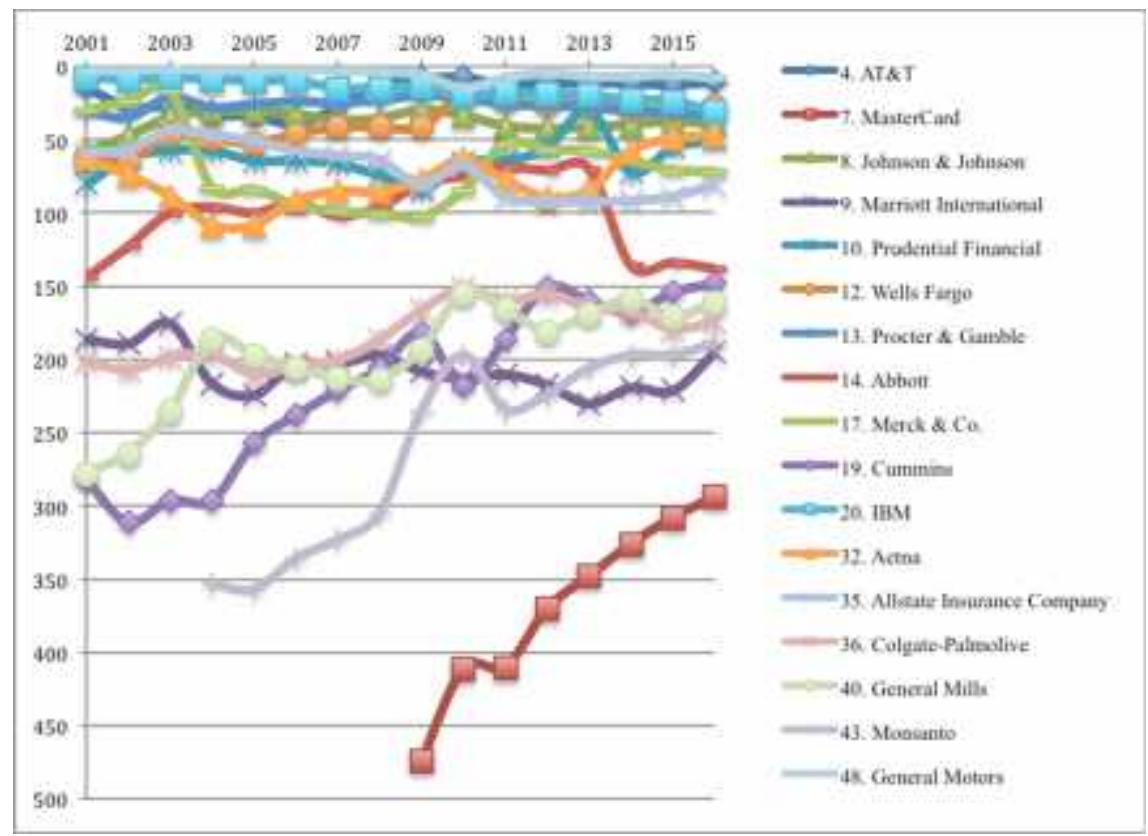

Fig. 2. Selected Diversity and Inclusion (D\&I) Fortune 500 Companies Rank (2001-2016)

\section{B. Analysis Model}

On the basis of the theories of Diversity Management that we have now gone through, we will do analysis approach of best practice from companies website and other online resources. Based on the arguments of diversity construct the competitive advantages, we will now point out some of the main themes characterizing the theories for Diversity Management in order for us to get the best practice as the companies need for productivity, innovation, and creativity to leverage diversity in entire business's ecosystem.

DiversityInc ranks the companies based on four management areas: CEO/Leadership commitment, talent pipeline, equitable talent development and supplier diversity. CEO/leadership commitment represent company vision and values on diversity and inclusion which come from highest management followed by all management level, its senior level and lower level. Talent pipeline represent workforce composition of women and all minorities. Equitable talent development represent that women and all minorities have developed equally among others. Supplier diversity show that company utilize women and minorities businesses owner to fulfill necessity goods and services.
To be a market leader, it is believed that a company must have competitive advantage compare to their competitors. Sustainable revenue growth may lead to the market share growth, even sometimes ordinary growth rate is not enough to make company as a market leader. But, Figure 2 could show us relation between four management areas of diversity and revenue growth. Thus, we construct a building blocks represent that four management areas of diversity are basis of competitive advantage development as shown at Table 2.

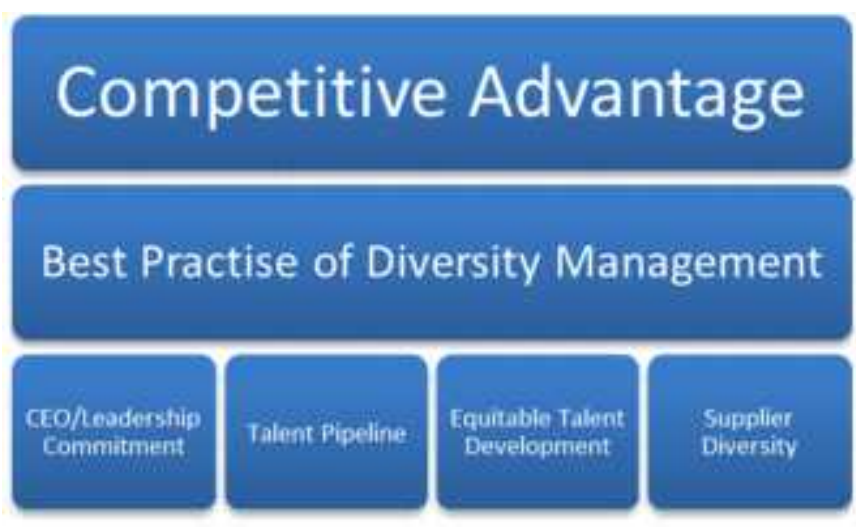

Fig. 3. Best Practise of Diversity Management - Competitive Advantage Framework 
TABLE II.

SELECTED DIVERSITY AND INCLUSION (D\&I) COMPANIES RANK

\begin{tabular}{|c|c|c|c|c|c|}
\hline \multirow{2}{*}{$\begin{array}{l}\text { D\&I } \\
\text { Rank } \\
(2016)\end{array}$} & \multirow{2}{*}{$\begin{array}{l}\text { Company } \\
\text { (Fortune Rank, } \\
\text { Revenue) }\end{array}$} & \multicolumn{4}{|c|}{ D\&I Management Area } \\
\hline & & CEO/Leadership Commitment & Talent Pipeline & Equitable Talent Development & Supplier Diversity \\
\hline $4(7)$ & $\begin{array}{c}\text { AT\&T } \\
(\# 10, \$ 146.8 \mathrm{~B})\end{array}$ & $\begin{array}{l}\text { Chairman's Diversity Council } \\
\text { reports and embeds diversity } \\
\text { into a total business strategy. }\end{array}$ & $\begin{array}{l}\text { Women in Technology and } \\
\text { the Project Management } \\
\text { Network engages a broader } \\
\text { group of employees and } \\
\text { campaigns to encourage } \\
\text { minorities for employment: } \\
\text { hiring sales representatives } \\
\text { to serve non-english } \\
\text { speaking customer }\end{array}$ & $\begin{array}{l}\text { increase career development } \\
\text { opportunities by ERG } \\
\text { Leadership Academies and } \\
\text { National ERG Conference }\end{array}$ & $\begin{array}{c}\text { Business Development } \\
\text { Program awards executive- } \\
\text { level scholarship and } \\
\text { graduates disabled veteran } \\
\text { owned business leaders } \\
\text { from mentoring program: } \\
\text { more than } 25 \% \text { of prime } \\
\text { suppliers are minority } \\
\text { owned }\end{array}$ \\
\hline $7(6)$ & $\begin{array}{c}\text { MasterCard } \\
(\# 294, \$ 9.6 \mathrm{~B})\end{array}$ & $\begin{array}{l}\text { Chief Diversity Officer consists } \\
\text { of senior management level } \\
\text { position responsible for } \\
\text { development and } \\
\text { implementation of the diversity } \\
\text { and inclusion strategy. }\end{array}$ & $\begin{array}{l}\text { global workforce diversity } \\
\text { which has more in common } \\
\text { with start-ups than } \\
\text { traditional industry giants }\end{array}$ & $\begin{array}{l}\text { half of employee participate in } 8 \\
\text { Business Resource Groups act } \\
\text { as internal business consultants } \\
\text { to provide consumer } \\
\text { segmentation, research, cultural } \\
\text { insights and access to networks. } \\
\text { with } 52 \text { chapters worldwide }\end{array}$ & $\begin{array}{l}\text { ensuring the demographics } \\
\text { of suppliers reflect } \\
\text { customers to address global } \\
\text { diverse marketplace needs, } \\
\text { joining coalition at } \\
\text { assessing minority-owned } \\
\text { business profitability }\end{array}$ \\
\hline $8(9)$ & $\begin{array}{c}\text { Johnson \& } \\
\text { Johnson } \\
(\# 39, \$ 70.1 \mathrm{~B})\end{array}$ & $\begin{array}{l}\text { chairman has mandated } \\
\text { excellence in diversity, created a } \\
\text { Global Office of Diversity \& } \\
\text { Inclusion, which reports directly } \\
\text { into him, and has provided } \\
\text { resources to ensure that the } \\
\text { Office of Global Diversity and } \\
\text { Inclusion achieves its vision }\end{array}$ & $\begin{array}{l}\text { promoting women in } \\
\text { management roles and } \\
\text { having women in all level } \\
\text { of management, } 45 \% \\
\text { female (43\% of as manager } \\
\& \text { director), new hires: } 50 \% \\
\text { female, } 68 \% \text { minorities }\end{array}$ & $\begin{array}{l}\text { ERG engage an estimated } \\
\text { 13,000 employees across } 186 \\
\text { U.S. chapters and } 18 \text { non-U.S. } \\
\text { chapters, joining } 10 \text { global } \\
\text { partnership to increase female } \\
\text { undergraduates studying } \\
\text { STEM2D }\end{array}$ & $\begin{array}{c}\text { spent } \$ 13.3 \text { billion to over } \\
7,500 \text { certified minority- } \\
\text { and women-owned business } \\
\text { suppliers ( } 2014) \text { and } \\
\text { increase by five percent } \\
\text { each year thereafter. }\end{array}$ \\
\hline $9(13)$ & $\begin{array}{c}\text { Marriot } \\
\text { International } \\
(\# 195, \$ 13.8 B)\end{array}$ & $\begin{array}{l}\text { top level management } \\
\text { commitment to diversity } \\
\text { (Committee for Excellence) } \\
\text { which comprised of senior-level } \\
\text { executives, regular meeting held } \\
\text { to identify diversity objectives at } \\
\text { all levels of the organization }\end{array}$ & $\begin{array}{c}\text { promoting blacks and } \\
\text { latinos into management } \\
\text { positions }\end{array}$ & $\begin{array}{l}\text { having } 18 \text { resource groups (D\&I } \\
\text { Councils and Associate } \\
\text { Networks), meets annually with } \\
\text { President and CEO }\end{array}$ & $\begin{array}{l}\text { procurement spent with } \\
\text { woman owned } \\
\text { subcontractors }\end{array}$ \\
\hline $10(8)$ & $\begin{array}{c}\text { Prudential } \\
\text { Financial } \\
(\# 50, \$ 57.1 \mathrm{~B})\end{array}$ & $\begin{array}{l}\text { CEO signs off on executive } \\
\text { compensation tied to diversity }\end{array}$ & $\begin{array}{l}\text { emphasize talent } \\
\text { development and formal } \\
\text { succession planning for } \\
\text { underrepresented groups, as } \\
\text { well as mandatory diverse } \\
\text { slates for executive } \\
\text { positions }\end{array}$ & $\begin{array}{c}\text { company has Business Resource } \\
\text { Groups (BRG) which have over } \\
75 \text { chapters, meets quarterly } \\
\text { with CEO }\end{array}$ & $\begin{array}{l}\text { provide opportunities for } \\
\text { purchasing products and } \\
\text { services from businesses } \\
\text { that reflect the } \\
\text { demographics of markets } \\
\text { contributes to the } \\
\text { sustainability of } \\
\text { communities, customers, } \\
\text { and company from qualified } \\
\text { diverse vendors }\end{array}$ \\
\hline
\end{tabular}




\begin{tabular}{|c|c|c|c|c|c|}
\hline \multicolumn{6}{|c|}{ (Table II, Cont.) } \\
\hline $12(11)$ & $\begin{array}{l}\text { Wells Fargo } \\
(\# 27, \$ 90 \mathrm{~B})\end{array}$ & $\begin{array}{l}\text { Enterprise Diversity and } \\
\text { Inclusion Councils led by CEO } \\
\text { to set and achieve diversity } \\
\text { goals, meets quarterly and its } \\
\text { goal is tied to executive } \\
\text { compensation. }\end{array}$ & $\begin{array}{l}\text { strive to leverage team } \\
\text { members' differences to } \\
\text { anticipate and meet the } \\
\text { needs of customers and } \\
\text { communities while tapping } \\
\text { into the innovation and } \\
\text { creativity that comes from } \\
\text { diverse perspectives: } 41 \% \\
\text { of U.S. workforce is } \\
\text { ethnically/racially diverse } \\
\text { - } 56 \% \text { of global workforce } \\
\text { is women } \\
\text { - } 8,200 \text { military veterans }\end{array}$ & $\begin{array}{l}\text { Formal mentoring program } \\
\text { involving all council members. } \\
\text { Women, Backs, Latinos, Asians } \\
\text { and Native Americans are } \\
\text { promoted into management and } \\
\text { joining formal succession- } \\
\text { planning programs }\end{array}$ & $\begin{array}{l}\text { ensure supplier diversity is } \\
\text { integrated into strategic } \\
\text { sourcing and procurement } \\
\text { processes to generate } \\
\text { efficiency, innovation and } \\
\text { increased opportunities for } \\
\text { first- and second-tier } \\
\text { diverse suppliers }\end{array}$ \\
\hline $13(10)$ & $\begin{array}{c}\text { Procter \& } \\
\text { Gamble } \\
(\# 34, \$ 78.8 \mathrm{~B})\end{array}$ & $\begin{array}{l}\text { CEO delivering consistent } \\
\text { leadership messages through all } \\
\text { levels of the organisation and } \\
\text { training general manager college } \\
\text { with values-based leadership } \\
\text { based on curriculum created }\end{array}$ & $\begin{array}{l}\text { P\&G's top leadership and } \\
\text { its HRSS team work closely } \\
\text { with Accenture to define the } \\
\text { data, processes and systems } \\
\text { (SAP-based) required to } \\
\text { enable workforce planning } \\
\text { process. }\end{array}$ & $\begin{array}{l}\text { SAP-based end-to-end talent } \\
\text { management } \\
\text { program has simplified } \\
\text { employee career and } \\
\text { performance management and } \\
\text { career development (as } \\
\text { indicated } \\
\text { by } 92 \text { percent of users) }\end{array}$ & $\begin{array}{l}\text { working on a new business } \\
\text { process that provides a } \\
\text { framework for driving } \\
\text { OTSR by addressing detail } \\
\text { important considerations } \\
\text { that will help improve the } \\
\text { outcome as well as make } \\
\text { the process more efficient }\end{array}$ \\
\hline $14(14)$ & $\begin{array}{c}\text { Abbott } \\
(\# 138, \$ 20.6 \mathrm{~B})\end{array}$ & $\begin{array}{l}\text { links executive compensation to } \\
\text { diversity metrics. executive } \\
\text { sponsor of an employee resource } \\
\text { group or a cross-cultural mentor. } \\
\text { Board of Directors evaluate } \\
\text { diversity results yearly. }\end{array}$ & $\begin{array}{l}\text { formal sponsorship for } \\
\text { high-potential employees } \\
\text { from underrepresented } \\
\text { groups. }\end{array}$ & $\begin{array}{l}\text { Executives at the top three } \\
\text { levels of the company, including } \\
\text { the CEO, all participate in a } \\
\text { formal mentoring program }\end{array}$ & $\begin{array}{l}\text { CEO personally signs off on } \\
\text { goals and achievements for } \\
\text { supplier diversity. company } \\
\text { requires its direct vendors to } \\
\text { mandate diversity among } \\
\text { the suppliers they work } \\
\text { with. }\end{array}$ \\
\hline $17(16)$ & $\begin{array}{l}\text { Merck \& Co. } \\
(\# 72, \$ 39.5 B)\end{array}$ & $\begin{array}{l}\text { Chairman and CEO who chairs } \\
\text { the executive diversity council, } \\
\text { is a visible supporter of } \\
\text { company commitment to } \\
\text { diversity. }\end{array}$ & $\begin{array}{l}\text { partnering with global and } \\
\text { national organization to } \\
\text { seek and attract minorities } \\
\text { candidate pool: } 42 \% \\
\text { women, } 72 \% \text { non-germany, } \\
24 \% \text { women of } \\
\text { management, } 61 \% \text { non- } \\
\text { germany management ( } 57 \\
\text { countries) }\end{array}$ & $\begin{array}{l}\text { various HR measures and global } \\
\text { management training programs } \\
\text { are used to address goal } \\
\text { objective of increasing } \\
\text { percentage of women in } \\
\text { management position this topic } \\
\text { and raise awareness among } \\
\text { executive staff }\end{array}$ & $\begin{array}{l}\text { proactively collaborate with } \\
\text { the client to identify } \\
\text { creative solutions to } \\
\text { challenging issues and } \\
\text { provide top-quality products } \\
\text { or services that are aligned } \\
\text { with company's business } \\
\text { needs and meet or exceed } \\
\text { expectations. }\end{array}$ \\
\hline $19(21)$ & $\begin{array}{c}\text { Cummins } \\
(\# 148, \$ 19.1 \mathrm{~B})\end{array}$ & $\begin{array}{l}\text { CEO post diversity statements, } \\
\text { held annual diversity town hall } \\
\text { meeting, make diversity goals } \\
\text { are part of executive- } \\
\text { performance reviews. }\end{array}$ & $\begin{array}{l}\text { women and country of birth } \\
\text { as key metric have got } \\
\text { attention from company to } \\
\text { ensure workforce resembles } \\
\text { demographics in the } \\
\text { countries and market where } \\
\text { it does business: } 26 \% \\
\text { women, } 20 \% \text { women leader }\end{array}$ & $\begin{array}{l}\text { has more than } 100 \text { resource- } \\
\text { group chapters nationwide and } \\
\text { project to update and expand } \\
\text { diversity training from a one- } \\
\text { time training to a layered } \\
\text { approach stretching across an } \\
\text { employee's time }\end{array}$ & $\begin{array}{l}\text { supplierdiversity. } \\
\text { cummins.com is a designed } \\
\text { to make it easier for diverse } \\
\text { suppliers to learn about the } \\
\text { opportunities at Cummins } \\
\text { and to tell diverse } \\
\text { businesses how to work } \\
\text { with }\end{array}$ \\
\hline
\end{tabular}




\begin{tabular}{|c|c|c|c|c|c|}
\hline \multicolumn{6}{|c|}{ (Table II, Cont.) } \\
\hline $20(22)$ & $\begin{array}{c}\text { IBM } \\
(\# 31, \$ 82,5 \mathrm{~B})\end{array}$ & $\begin{array}{l}\text { Company's diversity councils } \\
\text { headed by senior-level } \\
\text { executives, meet monthly and } \\
\text { set executive compensation ties } \\
\text { directly to diversity goals. }\end{array}$ & $\begin{array}{l}\text { Building Relationship and } \\
\text { Influence (BRI), is a } \\
\text { nomination-based award- } \\
\text { winning educational } \\
\text { program helps senior-level } \\
\text { women build business } \\
\text { relationships as well as } \\
\text { professional leadership } \\
\text { skills, has graduated more } \\
\text { than } 3,000 .\end{array}$ & $\begin{array}{c}\text { Company has } 148 \text { chapters of } \\
\text { employee resource groups } \\
\text { (ERGs) spread across } 45 \\
\text { countries serving various } \\
\text { groups, including women, } \\
\text { people with disabilities, LGBTs, } \\
\text { veterans, Asians and Blacks. }\end{array}$ & $\begin{array}{l}\text { supplier diversity program } \\
\text { expands purchasing } \\
\text { opportunities for businesses } \\
\text { owned and operated by } \\
\text { minorities, women, lesbian } \\
\text { and gay, veterans and } \\
\text { service disabled veterans, } \\
\text { and disabled persons, non- } \\
\text { profit organizations that } \\
\text { hire disabled persons and } \\
\text { for HUBZone companies. }\end{array}$ \\
\hline $32(32)$ & $\begin{array}{c}\text { Aetna } \\
(\# 46, \$ 60.3 \mathrm{~B})\end{array}$ & $\begin{array}{l}\text { Chairman, CEO and President is } \\
\text { the executive sponsor for } \\
\text { women's advancement } \\
\text { especially in leadership } \\
\text { positions }\end{array}$ & $\begin{array}{l}\text { company's targeted talent } \\
\text { strategy had a significant } \\
\text { impact on representation of } \\
\text { women at the executive } \\
\text { level and among executives, } \\
\text { leading P\&Ls greater than } \\
\text { \$1 billion. }\end{array}$ & $\begin{array}{l}\text { Women's Leadership Alliance } \\
\text { provides mentoring, coaching, } \\
\text { training and networking } \\
\text { opportunities to advance women } \\
\text { to executive positions through } \\
\text { Success Leadership program } \\
\text { and Success Sponsorship } \\
\text { program }\end{array}$ & $\begin{array}{l}\text { Supplier Diversity Program } \\
\text { builds solid business } \\
\text { relationships with certified } \\
\text { minority, women, LGBT } \\
\text { (lesbian, gay, bisexual, } \\
\text { transgender) and small- } \\
\text { business suppliers }\end{array}$ \\
\hline $35(33)$ & $\begin{array}{c}\text { Allstate } \\
\text { Insurance } \\
\text { Company } \\
(\# 81, \$ 35.2 \mathrm{~B})\end{array}$ & $\begin{array}{l}\text { Added tolerance, inclusion, and } \\
\text { diversity to the platform of The } \\
\text { Allstate Foundation, renew } \\
\text { accountablility and leadership } \\
\text { commitment to increase diverse } \\
\text { spend }\end{array}$ & $\begin{array}{l}\text { attracting team members } \\
\text { who value inclusive } \\
\text { diversity, equal opportunity } \\
\text { and work-life balance } \\
\text { provide unique service and } \\
\text { product offerings to a } \\
\text { diverse customer base. }\end{array}$ & $\begin{array}{l}\text { Company's } 10 \text { employee } \\
\text { resource groups utilizes social } \\
\text { networking to help employees } \\
\text { connect, while building business } \\
\text { relationships and creating a } \\
\text { sense of community. The groups } \\
\text { offer tailored mentoring } \\
\text { programs and events with } \\
\text { internal and external thought } \\
\text { leaders. }\end{array}$ & $\begin{array}{l}\text { annual Supplier Diversity } \\
\text { Exchange to provide an } \\
\text { opportunity for businesses } \\
\text { owned by minorities, } \\
\text { women, veterans, and } \\
\text { members of the lesbian, } \\
\text { gay, bisexual or transgender } \\
\text { community to build } \\
\text { relationships with Allstate } \\
\text { and Allstate's prime } \\
\text { suppliers }\end{array}$ \\
\hline $36(38)$ & $\begin{array}{c}\text { Colgate- } \\
\text { Palmolive } \\
(\# 174, \$ 16 \mathrm{~B})\end{array}$ & $\begin{array}{l}\text { Chairman, President and CEO } \\
\text { heads the Executive Diversity } \\
\text { Council, which meets regularly } \\
\text { with employee resource groups } \\
\text { to develop strategies for } \\
\text { attracting, developing and } \\
\text { retaining its diverse workforce. } \\
\text { Executive compensation has } \\
\text { attached to meeting or } \\
\text { exceeding diversity and } \\
\text { inclusion goals. }\end{array}$ & $\begin{array}{l}\text { focus on recruiting and } \\
\text { retaining a diverse global } \\
\text { workforce that reflects its } \\
\text { customer base around the } \\
\text { world: } 40 \% \text { women, } 85 \% \\
\text { non-US based }\end{array}$ & $\begin{array}{l}\text { Employee Resource Groups } \\
\text { developed in-house succession } \\
\text { planning and talent review } \\
\text { programs that help groom } \\
\text { multicultural workers for senior- } \\
\text { management positions }\end{array}$ & $\begin{array}{l}\text { runs a supplier diversity } \\
\text { program designed to reach } \\
\text { out and work with minority- } \\
\text { owned and women-owned } \\
\text { businesses for a number of } \\
\text { good and services, forms } \\
\text { partnerships with several } \\
\text { multicultural charities }\end{array}$ \\
\hline $40(19)$ & $\begin{array}{l}\text { General Mills } \\
(\# 161, \$ 17.6 \mathrm{~B})\end{array}$ & $\begin{array}{l}\text { CEO setting ambitious } \\
\text { numerical goals for the } \\
\text { representation of women and } \\
\text { people of color through strong } \\
\text { support for network group and } \\
\text { personal efforts to understand } \\
\text { the issues of women }\end{array}$ & $\begin{array}{l}\text { boasts powerful employee } \\
\text { networks, including the } \\
\text { Women's Network groups } \\
\text { Black Champions Network } \\
\text { that works to create culture } \\
\text { change and increase the } \\
\text { representation of women } \\
\text { and African-Americans }\end{array}$ & $\begin{array}{c}\text { reformulate and improve } \\
\text { Individual Development } \\
\text { Planning through Women's } \\
\text { Forum }\end{array}$ & $\begin{array}{l}\text { Supplier Diversity Office } \\
\text { facilitates a referral and } \\
\text { introduction to the buying } \\
\text { agent and encourages them } \\
\text { to use diverse suppliers } \\
\text { whenever and wherever } \\
\text { possible }\end{array}$ \\
\hline
\end{tabular}




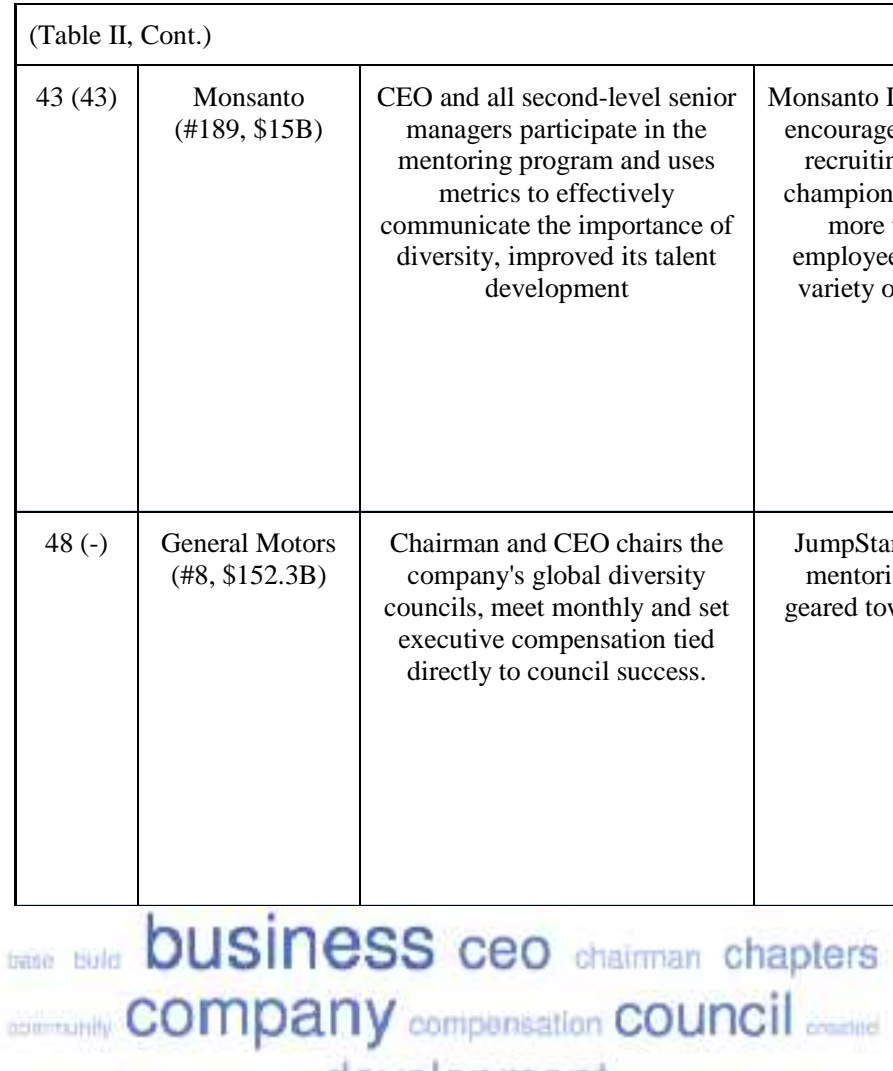

\section{diversity executive groups inclusion increase leadership level management meet marben $_{\text {mentoring }}$} minorities network opportunities owned parlluguth positions program provide mamanips resource numan subcess Supplier women

Fig. 4. Word Cloud Of Diversity Management Area

We might encounter that there is a mixture of the different approaches of best practice in the various companies, suggesting that in practice, the lines between different approaches are not about right or wrong. To help us simplify various techniques, we use a plain tool, Word Cloud. Fig. 4 represents the most prioritize activities to fulfill the diversity management objectives. It shows us these word of keys represent four management areas: executive, management, employee, mentoring, groups, council, supplier, etc. Table III shows arguments of diversity as contribution to competitive advantage

Fig. 5 represents the most prioritize arguments as contribution to competitive advantage. It shows that these arguments are the keys: customers, business, employee, development, ideas, markets, innovation, world, community etc. These key arguments will need activities to achieve its target. We can classify on three aspects: product, workforce and environment. Then we can construct these key activities:

- Innovate product which suit more diverse consumers and business

- Attract and develop diverse, market oriented employee to find more ideas and innovation

- Engage with customers and community to get insight of market demand

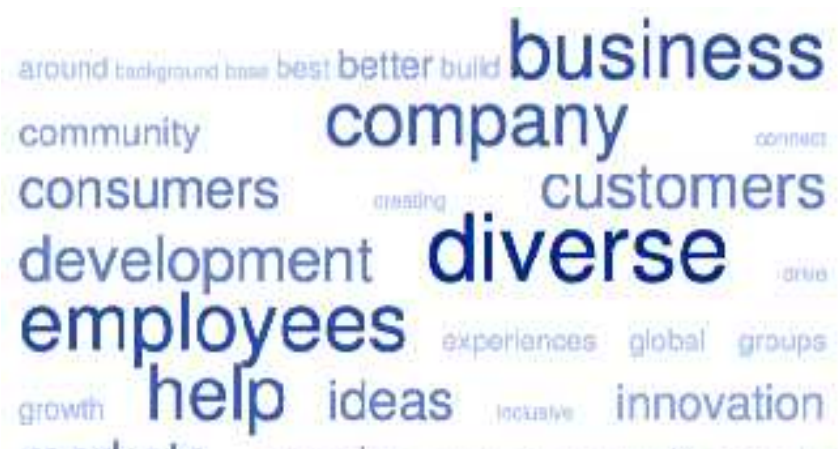

markets needs networks opportunity people

products pronisome programs provide med

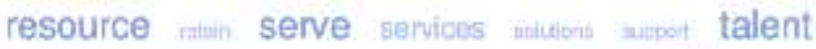
understand unique value work waxicio world

Fig. 5. Word Cloud Of Arguments Of Diversity As Contribution To Competitive Advantage 


\section{$\therefore$ ATLANTIS PRESS}

\section{CONCLUSION}

Today's global competition urges companies to innovate. Saturated domestic market because they have to expand. Companies have to innovate their products, resources and activities represent diverse needs. Diversity management should involve diversity on leadership commitment, workforce, development and business chain. Our findings shows that companies with the best practice in fostering and advancing diversity will able to maintain their revenue growth. These key activities are practiced: innovation on product and marketing, attracting and developing diverse employee and engaging with communities.

TABLE III. SELECTED DIVERSITY AND INCLUSION (D\&I) COMPANIES RANK

\begin{tabular}{|c|c|c|c|c|c|c|}
\hline \multirow{2}{*}{$\begin{array}{c}\text { D\&I } \\
\text { Rank } \\
(2016)\end{array}$} & \multirow{2}{*}{$\begin{array}{c}\text { Company } \\
\text { (Fortune } 500 \\
\text { Rank, Revenue) }\end{array}$} & \multicolumn{5}{|c|}{ Arguments } \\
\hline & & resource acquisition & resource maximization & creative problem solving & marketing & globalization \\
\hline $4(7)$ & $\begin{array}{c}\text { AT\&T (\#10) } \\
\$ 146.8 \mathrm{~B})\end{array}$ & $\begin{array}{c}\text { campaign to } \\
\text { encourage veterans, } \\
\text { LGBT and people } \\
\text { with disabilities to } \\
\text { self identify in order } \\
\text { to better capture } \\
\text { diversity statistics }\end{array}$ & $\begin{array}{l}\text { comprehensive leadership } \\
\text { development programs, } \\
\text { online courses, and } \\
\text { resources helps } \\
\text { employees achieve their } \\
\text { personal and professional } \\
\text { goals }\end{array}$ & $\begin{array}{l}\text { employees collaborate with } \\
\text { internal crowd-sourcing tool } \\
\text { and innovation centers } \\
\text { where tech leaders and } \\
\text { start-ups connect to develop } \\
\text { new ideas }\end{array}$ & $\begin{array}{l}\text { hiring non-english } \\
\text { spoken sales } \\
\text { representatives for } \\
\text { serving more diverse } \\
\text { customers }\end{array}$ & $\begin{array}{c}\text { ERG with } 5 \\
\text { international } \\
\text { employee networks } \\
\text { to support } \\
\text { communities, drive } \\
\text { diversity } \\
\text { awareness, partner } \\
\text { to grow our } \\
\text { business }\end{array}$ \\
\hline $7(6)$ & $\begin{array}{c}\text { MasterCard } \\
(\# 294, \$ 9.6 B)\end{array}$ & $\begin{array}{l}\text { A diverse workforce } \\
\text { gives a broader range } \\
\text { of ideas, insights and } \\
\text { experiences to } \\
\text { develop new } \\
\text { products and } \\
\text { services. }\end{array}$ & $\begin{array}{l}\text { respecting individual } \\
\text { strengths, views and } \\
\text { experiences helps } \\
\text { employees to reach their } \\
\text { best and brigthness, full } \\
\text { potential }\end{array}$ & $\begin{array}{c}\text { BRG involves and } \\
\text { empowers employees to } \\
\text { take an active role in their } \\
\text { own development and to } \\
\text { lead initiatives }\end{array}$ & $\begin{array}{l}\text { able to gain a deeper } \\
\text { understanding of } \\
\text { customers' unique } \\
\text { needs through a } \\
\text { workforce that reflects } \\
\text { the market }\end{array}$ & $\begin{array}{l}\text { employees are } \\
\text { empowered to } \\
\text { work on cross- } \\
\text { functional projects } \\
\text { or volunteer for } \\
\text { rotational } \\
\text { assignments reach } \\
\text { market into more } \\
\text { than } 210 \text { countries }\end{array}$ \\
\hline $8(9)$ & $\begin{array}{c}\text { Johnson \& } \\
\text { Johnson (\#39, } \\
\text { \$70.1B) }\end{array}$ & $\begin{array}{l}\text { hires individuals } \\
\text { ready to infuse } \\
\text { unique perspectives, } \\
\text { background, and } \\
\text { experiences into } \\
\text { business process and } \\
\text { thinking can expands } \\
\text { innovation }\end{array}$ & $\begin{array}{l}\text { The Johnson \& Johnson } \\
\text { Diversity University help } \\
\text { employees understand } \\
\text { and value differences and } \\
\text { the benefits of working } \\
\text { collaboratively to meet } \\
\text { business goals }\end{array}$ & $\begin{array}{l}\text { Office of Diversity \& } \\
\text { Inclusion creates an open } \\
\text { forum to exchange ideas } \\
\text { and to strengthen the } \\
\text { linkage to and within } \\
\text { diverse communities }\end{array}$ & $\begin{array}{l}\text { working with small and } \\
\text { diverse suppliers can } \\
\text { support long-term } \\
\text { growth and add value } \\
\text { to businesses by } \\
\text { providing innovative } \\
\text { solutions to marketing }\end{array}$ & $\begin{array}{l}\text { expanding business } \\
\text { portfolio, based on } \\
\text { successful of China } \\
\text { model, gives a } \\
\text { unique ability to } \\
\text { meet the needs of } \\
\text { the emerging } \\
\text { markets }\end{array}$ \\
\hline $9(13)$ & $\begin{array}{c}\text { Marriot } \\
\text { International } \\
(\# 195, \$ 13.8 B)\end{array}$ & $\begin{array}{l}\text { embrace the unique } \\
\text { talents who speak } \\
\text { different languages in } \\
\text { countries and } \\
\text { territories will help } \\
\text { corporate meet the } \\
\text { changing needs of } \\
\text { customers }\end{array}$ & $\begin{array}{l}\text { development of } \\
\text { multigenerational } \\
\text { workforce to focus on } \\
\text { valuing diversity and } \\
\text { fostering an inclusive } \\
\text { environment }\end{array}$ & $\begin{array}{c}\text { diversify ownership } \\
\text { portfolio to provide a } \\
\text { competitive advantage and } \\
\text { to enhance sustainable } \\
\text { business growth, as well as } \\
\text { both economic and social } \\
\text { vitality. }\end{array}$ & $\begin{array}{l}\text { marketing campaign } \\
\text { focusing on African- } \\
\text { American, Hispanic } \\
\text { and LGBT travelers, } \\
\text { friends and families } \\
\text { makes Marriott a great } \\
\text { place to work, conduct } \\
\text { business and stay. }\end{array}$ & $\begin{array}{c}\text { grow and } \\
\text { strengthen } \\
\text { relationships with } \\
\text { minority- and } \\
\text { woman-, service } \\
\text { veteran-, disabled-, } \\
\text { and LGBT-owned } \\
\text { businesses around } \\
\text { the globe } \\
\text { continualy will } \\
\text { help company to } \\
\text { meet the needs of } \\
\text { broader markets }\end{array}$ \\
\hline
\end{tabular}




\begin{tabular}{|c|c|c|c|c|c|c|}
\hline \multicolumn{7}{|c|}{ (Table III, Cont.) } \\
\hline $10(8)$ & $\begin{array}{c}\text { Prudential } \\
\text { Financial (\#50, } \\
\$ 57.1 \mathrm{~B})\end{array}$ & $\begin{array}{l}\text { Getting the best ideas } \\
\text { from employees of } \\
\text { all backgrounds } \\
\text { around the world and } \\
\text { building a pipeline of } \\
\text { diverse, rising talent } \\
\text { are essential to } \\
\text { company growth and } \\
\text { competitive } \\
\text { advantage }\end{array}$ & $\begin{array}{c}\text { competitive } \\
\text { compensation and } \\
\text { benefits, state-of-the-art } \\
\text { learning and development } \\
\text { initiatives to helping } \\
\text { employee succeed both } \\
\text { professionally and } \\
\text { personally }\end{array}$ & $\begin{array}{l}\text { seek talented, creative } \\
\text { individuals from a variety } \\
\text { of backgrounds, worldviews } \\
\text { and life circumstances to } \\
\text { build inclusive workplace, } \\
\text { to welcome new ideas and } \\
\text { to appreciate valuable } \\
\text { experience }\end{array}$ & $\begin{array}{l}\text { including wide range of } \\
\text { partners and suppliers } \\
\text { to expand } \\
\text { understanding of } \\
\text { markets and our } \\
\text { opportunities to help } \\
\text { others. }\end{array}$ & $\begin{array}{l}\text { respect and reach } \\
\text { out to diverse } \\
\text { consumers and } \\
\text { communities to } \\
\text { partner with them } \\
\text { to meet their } \\
\text { current needs, } \\
\text { support their } \\
\text { dreams and build } \\
\text { their futures }\end{array}$ \\
\hline $12(11)$ & $\begin{array}{l}\text { Wells Fargo } \\
(\# 27, \$ 90 \mathrm{~B})\end{array}$ & $\begin{array}{l}\text { strive for a culture } \\
\text { with inclusive } \\
\text { policies and } \\
\text { programs that attract, } \\
\text { develop, engage, and } \\
\text { retain the best talent. }\end{array}$ & $\begin{array}{c}\text { promote formal } \\
\text { mentoring programs, } \\
\text { succession-planning } \\
\text { programs and encourage } \\
\text { minorities into } \\
\text { management as place to } \\
\text { connect, leverage, learn, } \\
\text { build their skills, and } \\
\text { impact business } \\
\text { outcomes. }\end{array}$ & $\begin{array}{l}\text { Foster the exchange of ideas } \\
\text { by hosting summits and } \\
\text { joining Team Member } \\
\text { Networks consisting of } \\
\text { individuals who come } \\
\text { together because of a shared } \\
\text { background, experience or } \\
\text { other affiliation. }\end{array}$ & $\begin{array}{l}\text { joining Team Member } \\
\text { Networks to educate on } \\
\text { the best ways to reach } \\
\text { and serve diverse } \\
\text { market segments. }\end{array}$ & $\begin{array}{l}\text { commitment to } \\
\text { D\&I is a business } \\
\text { imperative to take } \\
\text { advantage of the } \\
\text { creativity and } \\
\text { innovation from } \\
\text { multiple } \\
\text { perspectives, to see } \\
\text { business } \\
\text { opportunities in } \\
\text { new ways, to } \\
\text { respond and } \\
\text { understand fully, } \\
\text { quickly and } \\
\text { effectively to } \\
\text { customer needs, } \\
\text { and succeed in } \\
\text { serving the needs } \\
\text { of all customers. }\end{array}$ \\
\hline $13(10)$ & $\begin{array}{c}\text { Procter \& } \\
\text { Gamble (\#34, } \\
\text { \$78.8B) }\end{array}$ & $\begin{array}{l}\text { By actively } \\
\text { recruiting, engaging } \\
\text { and retaining talented } \\
\text { individuals from } \\
\text { around the world, } \\
\text { company has the } \\
\text { opportunity to } \\
\text { continue to develop a } \\
\text { workforce that is as } \\
\text { diverse as the } \\
\text { customers they serve }\end{array}$ & $\begin{array}{l}\text { Corporate-sponsored } \\
\text { Affinity Groups are } \\
\text { closely involved in } \\
\text { professional networking, } \\
\text { development, training and } \\
\text { education ensuring } \\
\text { everyone performing at } \\
\text { their peak }\end{array}$ & $\begin{array}{l}\text { put a diverse team together } \\
\text { will have a much better } \\
\text { chance of coming up with } \\
\text { something that's new, fresh } \\
\text { and exciting in creating } \\
\text { brands and products to } \\
\text { improve the lives of the } \\
\text { world's consumers now and } \\
\text { in the future. }\end{array}$ & $\begin{array}{l}\text { Through the grassroots } \\
\text { and the Corporate } \\
\text { Affinity groups, } \\
\text { employees have a } \\
\text { structured opportunity } \\
\text { for connecting and } \\
\text { building a strong sense } \\
\text { of community, as well } \\
\text { as supporting the } \\
\text { Company in delivering } \\
\text { better business results. }\end{array}$ & $\begin{array}{l}\text { Gaining valuable } \\
\text { insights from } \\
\text { employee groups is } \\
\text { one way to ensure } \\
\text { that company is in } \\
\text { touch with } \\
\text { consumers around } \\
\text { the world. }\end{array}$ \\
\hline $14(14)$ & $\begin{array}{l}\text { Abbott (\#138, } \\
\$ 20.6 \mathrm{~B})\end{array}$ & $\begin{array}{l}\text { recruiting people } \\
\text { with diverse } \\
\text { experiences and } \\
\text { perspectives through } \\
\text { partnering with } \\
\text { professional and } \\
\text { academic } \\
\text { organizations will } \\
\text { strengthen pipeline of } \\
\text { diverse talent }\end{array}$ & $\begin{array}{l}\text { formal mentoring } \\
\text { program supported by } \\
\text { relationship-oriented } \\
\text { culture gives employees } \\
\text { the opportunity to work } \\
\text { with fellow co-workers in } \\
\text { structured, year-long } \\
\text { developmental } \\
\text { partnerships }\end{array}$ & $\begin{array}{l}\text { companies realize with } \\
\text { more diversity among their } \\
\text { people think more } \\
\text { creatively to help company } \\
\text { solve some of the world's } \\
\text { most pressing healthcare } \\
\text { challenges }\end{array}$ & $\begin{array}{l}\text { companies with more } \\
\text { diversity among their } \\
\text { people adapt more } \\
\text { quickly to changing } \\
\text { markets. }\end{array}$ & $\begin{array}{l}\text { global company } \\
\text { need a wide } \\
\text { diversity of ideas } \\
\text { and perspectives to } \\
\text { understand the } \\
\text { people company } \\
\text { serve and be } \\
\text { relevant to their } \\
\text { lives }\end{array}$ \\
\hline
\end{tabular}




\begin{tabular}{|c|c|c|c|c|c|c|}
\hline \multicolumn{7}{|c|}{ (Table III, Cont.) } \\
\hline $17(16)$ & $\begin{array}{l}\text { Merck \& Co. } \\
(\# 72, \$ 39.5 B)\end{array}$ & $\begin{array}{l}\text { global diverse } \\
\text { workforce makes } \\
\text { company better } \\
\text { attuned to the needs } \\
\text { of customers, health } \\
\text { care providers and } \\
\text { patients who } \\
\text { ultimately use the } \\
\text { products }\end{array}$ & $\begin{array}{l}\text { Making sure all } \\
\text { employees feel valued, } \\
\text { respected and given } \\
\text { access to the } \\
\text { opportunities that help } \\
\text { them grow in their careers } \\
\text { and enable them to add } \\
\text { value to our business }\end{array}$ & $\begin{array}{l}\text { increase the minority } \\
\text { participation in clinical trial } \\
\text { tests how well new medical } \\
\text { approaches work in people } \\
\text { is important as these } \\
\text { subjects reflect our } \\
\text { population }\end{array}$ & $\begin{array}{l}\text { understands dynamic } \\
\text { millenials demand can } \\
\text { help address the needs } \\
\text { of an increasingly } \\
\text { diverse base of patients, } \\
\text { customers, employees } \\
\text { and suppliers. }\end{array}$ & $\begin{array}{l}\text { work closely with } \\
\text { global diverse } \\
\text { suppliers network } \\
\text { to provide the } \\
\text { highest level of } \\
\text { service to } \\
\text { customers and } \\
\text { achieve a win-win } \\
\text { business } \\
\text { relationship. }\end{array}$ \\
\hline $19(21)$ & $\begin{array}{c}\text { Cummins (\#148, } \\
\$ 19.1 \mathrm{~B})\end{array}$ & $\begin{array}{l}\text { employs workforce } \\
\text { that understands } \\
\text { complex issues at } \\
\text { local levels can } \\
\text { operate successfully } \\
\text { within the Company's } \\
\text { value system to deal }\end{array}$ & $\begin{array}{l}\text { training for diverse } \\
\text { employees makes } \\
\text { company develop better } \\
\text { creative solutions to } \\
\text { difficult business } \\
\text { problems }\end{array}$ & $\begin{array}{l}\text { directs employees to partner } \\
\text { with customers to provide } \\
\text { innovative products and } \\
\text { services that meet customer } \\
\text { expectations and help them } \\
\text { succeed }\end{array}$ & $\begin{array}{l}\text { reflect marketing as } \\
\text { increasingly diverse } \\
\quad \text { customer base, } \\
\text { especially as it enters } \\
\text { new markets to boost } \\
\text { sales generate }\end{array}$ & $\begin{array}{l}\text { operate across } \\
\text { cultures, functions, } \\
\text { language barriers } \\
\text { and time zones to } \\
\text { solve the technical } \\
\text { and logistical } \\
\text { challenges created } \\
\text { by a worldwide } \\
\text { customer base. }\end{array}$ \\
\hline $20(22)$ & $\begin{array}{l}\text { IBM (\#31, } \\
\$ 82,5 B)\end{array}$ & $\begin{array}{l}\text { carries out programs } \\
\text { on behalf of women, } \\
\text { minorities, people } \\
\text { with disabilities, and } \\
\text { protected veterans } \\
\text { covered under the } \\
\text { law will positively } \\
\text { distinguished } \\
\text { company and made a } \\
\text { magnet for the } \\
\text { smartest and most } \\
\text { talented people in the } \\
\text { world }\end{array}$ & $\begin{array}{l}\text { includes outreach as well } \\
\text { as human resource } \\
\text { programs that ensure } \\
\text { equity in compensation } \\
\text { and opportunity for } \\
\text { growth and development } \\
\text { to provide equal } \\
\text { opportunity }\end{array}$ & $\begin{array}{l}\text { Building and maintaining a } \\
\text { community of diverse } \\
\text { suppliers increases } \\
\text { opportunity to hear new } \\
\text { ideas, apply different } \\
\text { approaches, and gain access } \\
\text { to additional solutions that } \\
\text { respond to customer needs }\end{array}$ & $\begin{array}{l}\text { show diverse business } \\
\text { owners how to } \\
\text { accelerate the growth } \\
\text { of their businesses by } \\
\text { marrying their } \\
\text { technology, business } \\
\text { strategies and } \\
\text { leveraging company } \\
\text { solutions to provide } \\
\text { innovative solutions to } \\
\text { their marketplace. }\end{array}$ & $\begin{array}{l}\text { partner with many } \\
\text { organizations both } \\
\text { local and global to } \\
\text { places great } \\
\text { emphasis on the } \\
\text { role of technology } \\
\text { as a tool to address } \\
\text { societal issues and } \\
\text { demonstrate } \\
\text { reputation as a } \\
\text { solutions provider }\end{array}$ \\
\hline $32(32)$ & $\begin{array}{l}\text { Aetna (\#46, } \\
\$ 60.3 \mathrm{~B})\end{array}$ & $\begin{array}{l}\text { focus on developing } \\
\text { and advancing } \\
\text { women employees as } \\
\text { represent largest } \\
\text { consumer group, they } \\
\text { influence } 80 \% \text { of } \\
\text { purchasing decisions } \\
\text { today }\end{array}$ & $\begin{array}{l}\text { representation of women } \\
\text { at the executive level and } \\
\text { among executives leading } \\
\text { P\&Ls greater than } \$ 1 \\
\text { billion }\end{array}$ & $\begin{array}{c}\text { Employee resource groups } \\
\text { bring together people with } \\
\text { shared support business } \\
\text { objectives by guiding the } \\
\text { development of new } \\
\text { products, services and } \\
\text { advertising }\end{array}$ & $\begin{array}{l}\text { Doing business with } \\
\text { diverse suppliers helps } \\
\text { us to better understand } \\
\text { and serve our multi- } \\
\text { cultural markets. }\end{array}$ & $\begin{array}{l}\text { Doing business } \\
\text { with underutilized } \\
\text { supliers is a key } \\
\text { part of how } \\
\text { purchasing a } \\
\text { broader range of } \\
\text { high quality goods } \\
\text { and services and } \\
\text { helps company } \\
\text { understand and } \\
\text { serve multicultural } \\
\text { world better }\end{array}$ \\
\hline $35(33)$ & $\begin{array}{c}\text { Allstate } \\
\text { Insurance } \\
\text { Company (\#81, } \\
\$ 35.2 \mathrm{~B})\end{array}$ & $\begin{array}{l}\text { workplace diversity } \\
\text { strategy helps attract } \\
\text { and retain high } \\
\text { quality recruits and } \\
\text { provide unique } \\
\text { service and product } \\
\text { offerings to a diverse } \\
\text { customer base }\end{array}$ & $\begin{array}{l}\text { employee resource groups } \\
\text { help staff build } \\
\text { relationships with one } \\
\text { another and offer a } \\
\text { community for employees } \\
\text { to share common } \\
\text { interests, aspirations and } \\
\text { collaborate together }\end{array}$ & $\begin{array}{l}\text { Leveraging breadth of } \\
\text { differences as company } \\
\text { strength will drives high } \\
\text { performance culture and } \\
\text { helps us create the } \\
\text { innovative solutions need to } \\
\text { help customers live a good } \\
\text { life }\end{array}$ & $\begin{array}{l}\text { number of tools and } \\
\text { resources available, } \\
\text { along with a team of } \\
\text { dedicated agents } \\
\text { working nationwide to } \\
\text { help our customers } \\
\text { better understand their } \\
\text { insurance policy and } \\
\text { decide what products } \\
\text { will best serve their } \\
\text { unique needs }\end{array}$ & $\begin{array}{l}\text { employee resource } \\
\text { groups tap into the } \\
\text { power of social } \\
\text { networking to help } \\
\text { employees } \\
\text { connect, while } \\
\text { building business } \\
\text { relationships and } \\
\text { creating a sense of } \\
\text { community }\end{array}$ \\
\hline
\end{tabular}




\begin{tabular}{|c|c|c|c|c|c|c|}
\hline \multicolumn{7}{|c|}{ (Table III, Cont.) } \\
\hline $36(38)$ & $\begin{array}{c}\text { Colgate- } \\
\text { Palmolive }(\# 174, \\
\$ 16 \mathrm{~B})\end{array}$ & $\begin{array}{l}\text { focus on recruiting } \\
\text { and retaining a } \\
\text { diverse global } \\
\text { workforce that } \\
\text { reflects its customer } \\
\text { base around the } \\
\text { world }\end{array}$ & $\begin{array}{l}\text { constantly strengthening } \\
\text { mentoring, training and } \\
\text { work/life balance } \\
\text { programs in an effort to } \\
\text { ensure that all employees } \\
\text { have access to } \\
\text { professional and personal } \\
\text { development } \\
\text { opportunities }\end{array}$ & $\begin{array}{l}\text { Diversity of thinking will } \\
\text { help company continue to } \\
\text { encourage the creativity and } \\
\text { innovation necessary for } \\
\text { maintaining a competitive } \\
\text { advantage in the global } \\
\text { marketplace. }\end{array}$ & $\begin{array}{l}\text { introduction of } \\
\text { products and services } \\
\text { to a diverse group of } \\
\text { consumers consistent } \\
\text { with their cultural and } \\
\text { lifestyle preferences to } \\
\text { acknowledges the } \\
\text { cultural nuances in a } \\
\text { respectful way }\end{array}$ & $\begin{array}{l}\text { focus on driving } \\
\text { growth in fastest } \\
\text { growing consumer } \\
\text { markets in both } \\
\text { numbers and } \\
\text { purchasing power } \\
\text { to know company } \\
\text { global consumers } \\
\text { and develop } \\
\text { products that fit } \\
\text { their needs. }\end{array}$ \\
\hline $40(19)$ & $\begin{array}{l}\text { General Mills } \\
(\# 161, \$ 17.6 \mathrm{~B})\end{array}$ & $\begin{array}{l}\text { retaining employees } \\
\text { who represent the } \\
\text { broad spectrum of } \\
\text { society to drive } \\
\text { innovation and } \\
\text { effectively connect } \\
\text { with consumers } \\
\text { around the world }\end{array}$ & $\begin{array}{l}\text { established an Executive } \\
\text { Diversity Council, } \\
\text { comprised of the } \\
\text { company's most senior } \\
\text { leaders to reinforce } \\
\text { inclusion across all levels } \\
\text { and divisions of the } \\
\text { company }\end{array}$ & $\begin{array}{l}\text { Bringing unique ideas and } \\
\text { perspectives help drive } \\
\text { breakthrough innovation } \\
\text { and assist in effectively } \\
\text { connecting with consumers } \\
\text { to drive mutually beneficial } \\
\text { growth }\end{array}$ & $\begin{array}{l}\text { differential thinking, } \\
\text { experiences and } \\
\text { insights to deliver } \\
\text { sustainable growth and } \\
\text { drive competitive } \\
\text { advantage in } \\
\text { increasingly complex } \\
\text { marketplace }\end{array}$ & $\begin{array}{l}\text { having teams } \\
\text { reflect the wide } \\
\text { expanse of } \\
\text { consumers helps us } \\
\text { ensure that the } \\
\text { ideas bring to the } \\
\text { table will be the } \\
\text { best in the world }\end{array}$ \\
\hline $43(43)$ & $\begin{array}{l}\text { Monsanto (\#189, } \\
\quad \$ 15 \mathrm{~B})\end{array}$ & $\begin{array}{l}\text { attract and retain } \\
\text { talented employees } \\
\text { with broad } \\
\text { experiences and } \\
\text { backgrounds that } \\
\text { bring new and } \\
\text { innovative ideas and } \\
\text { viewpoints to } \\
\text { organization }\end{array}$ & $\begin{array}{l}\text { further the employee } \\
\text { professional development } \\
\text { through business resource } \\
\text { networks can make their } \\
\text { fullest contribution to the } \\
\text { achievement of corporate } \\
\text { goals and objectives }\end{array}$ & $\begin{array}{l}\text { Creating an inclusive } \\
\text { environment which } \\
\text { welcoming, respecting and } \\
\text { valuing ideas, dialogue and } \\
\text { perspectives will lead to } \\
\text { greater value creation }\end{array}$ & $\begin{array}{l}\text { employee with variety } \\
\text { of background come up } \\
\text { wide range of ideas and } \\
\text { resources is required } \\
\text { for making a } \\
\text { sustainable balanced } \\
\text { product accessible to } \\
\text { everyone }\end{array}$ & $\begin{array}{l}\text { diverse business } \\
\text { perspectives and } \\
\text { the flexibility to } \\
\text { work with a variety } \\
\text { of people wherever } \\
\text { we conduct } \\
\text { business will } \\
\text { sustain and grow } \\
\text { business across all } \\
\text { world areas }\end{array}$ \\
\hline $48(-)$ & $\begin{array}{c}\text { General Motors } \\
(\# 8, \$ 152.3 \mathrm{~B})\end{array}$ & $\begin{array}{l}\text { Finding and growing } \\
\text { the best and brightest } \\
\text { talent from around } \\
\text { the world which tied } \\
\text { to ERG business plan } \\
\text { are critical to } \\
\text { maintaining GM's } \\
\text { position as a global } \\
\text { leader }\end{array}$ & $\begin{array}{l}\text { mentoring program } \\
\text { connects senior leaders } \\
\text { with new employees } \\
\text { through a one-on-one } \\
\text { reverse mentoring } \\
\text { partnership resulting in a } \\
\text { better understanding of } \\
\text { the unique generational } \\
\text { challenges and issues } \\
\text { facing new employees }\end{array}$ & $\begin{array}{l}\text { ERGs provide insights that } \\
\text { help better understand into } \\
\text { diverse and emerging } \\
\text { consumer markets, offering } \\
\text { a platform for our } \\
\text { employees to contribute to } \\
\text { diversity initiatives within } \\
\text { our community. }\end{array}$ & $\begin{array}{l}\text { ensuring company } \\
\text { position in capitalizing } \\
\text { the best resources on } \\
\text { new and emerging } \\
\text { consumer trends } \\
\text { through Diversity } \\
\text { Marketing Center of } \\
\text { Expertise }\end{array}$ & $\begin{array}{l}\text { managing by } \\
\text { Dealer } \\
\text { Development, } \\
\text { dealerships are } \\
\text { integral } \\
\text { to the distribution } \\
\text { of product and } \\
\text { serve as the local } \\
\text { face of company } \\
\text { in communities } \\
\text { around the world to } \\
\text { create a profitable } \\
\text { dealer network } \\
\text { across all brands } \\
\text { that reflect } \\
\text { consumer diversity }\end{array}$ \\
\hline
\end{tabular}

\section{REFERENCES}

[1] Marilyn Loden and Julie Rosener, Workforce America; Business One Irwin, 1991.

[2] Konrad, A.M., Prasad, P and Pringle, J.K, Handbook of workplace diversity, London.

[3] Sammi Soutar, CAE, Beyond the Rainbow: infusing your organization with diversity know-how, Association Management 2004.

[4] Yang, Y. (2005). Developing cultural diversity advantage: The impact of diversity management structures. Academy of Management Best Conference Paper.
[5] Vivian Hunt, Dennis Layton, Sara Prince, "Diversity Matters", McKinsey and Company, 2014.

[6] Stacia Garr, Candace Atamanik, High-Impact Talent Management: The New Talent Management Maturity Model, Deloitte, 2015.

[7] Dictionary.com, 2016

[8] Coats, R., Goodwin, J., \& Bangs, P. (2000). Seeking the best path: Assessing a library's diversity climate. Library Administration \& Management, 14, 148-154.

[9] Lauring, J., \& Ross, C. (2004). Research notes: Cultural diversity and organizational efficiency. New Zealand Journal of Employment Relation, 29(1), 89-103.

[10] Pitts, D.W. (2006). Modeling the impact of diversity management. Review of Public Personnel Administration, 26, 245-268. 
[11] Aronson, D. (2002). Managing the diversity revolution: Best practices for 21st century business. Civil Rights Journal, 6, 46-66.
[12] Managing Cultural Diversity: Implications for Organizational Competitiveness, Taylor H. Cox and Stacy Blake,The Executive, Vol. 5, No. 3 (Aug., 1991), pp. 45-56. 